\title{
GLL
}

0ص Geomatics, Landmanagement and Landscape No. $2 \cdot 2019,63-75$

\section{COMPARATIVE ANALYSIS OF SELECTED DATABASES OF SPATIAL INFORMATION SYSTEMS, WITH THE VIEW TO MEETING THE NEEDS OF REAL ESTATE PROPERTY VALUATION IN POLAND - A CASE STUDY}

\author{
Magdalena Jurkiewicz
}

\section{Summary}

This publication is a case study on the analysis of the level of detail of the selected Local Spatial Information System in Poland, in terms of the content of databases and the possibility of using them in property valuation. The scope of research covered in particular the Spatial Information System (SIS) for the city of Częstochowa, operating as part of a project co-financed by the European Union from the European Regional Development Fund under the Regional Operational Program of the Silesia Region for the years 2007-2013. The main purpose of implementing this system is to increase the availability and scope of public services provided electronically, as well as to simplify and speed up administrative procedures. In this publication, we present results of research that was carried out in order to determine the suitability of information collected in the analysed system for the purposes of preparing an appraisal (property valuation) report by a property appraiser. The case study contains a comparative analysis of information available in the Częstochowa spatial information system with similar systems operating in several selected cities. These include the SIS for Kraków, Wrocław and the capital city of Warsaw. Studies have shown that Kraków's city portal is the most useful in terms of property valuation needs, while the information contained in the Częstochowa spatial information system is not sufficient.

\section{Keywords}

spatial information system $\bullet$ property valuation

\section{Introduction}

Spatial information systems have been operating in the world since the early 1950s. This problem has been presented in numerous studies by authors such as Williamson [1985], Fourie [1998], Zhao and Zhou [1999], Fourie and Nino-Fluck [2000], Redman [2001], Nkambwe [2001], Elia et al. [2013], Aranas et al. [2014]. In Poland, among the authors dealing with the study of geoportals, we should list Gaździcki [1990], Dukaczewski [2007], Kozubek and Werner [2009], Siejka [2011], Ślusarski [2006, 2012a, 2012b], 
Siejka and Ślusarski [2012, 2013, 2014], Jurkiewicz [2015], Leń and Tempiński [2015], Mika [2017], Dawidowicz and Klimach [2017]. Similar research, in particular on the Kraków's City Spatial Information System, is included in the monograph by multiple authors, edited by Kwartnik-Pruc [2015].

In the literature of the subject, attention is drawn to spatial information systems as a valuable source of information about real estate, whereas universal access is their important feature. The need to control the quality of available spatial information systems as well as increase the completeness of data contained therein is also stressed. The assessment of the quality of available websites shows that the local government administration performs obligations under the Act on spatial information infrastructure [Act 2010] at a satisfactory level. This facilitates the verification of their suitability in terms of needs: not only of residents, but also of investors, surveyors or appraisers.

The intensification of development work on the construction of geoportals resulted from the introduction of legal regulations for the creation and operation of the Spatial Information Infrastructure. Throughout Europe, the legal norm in this matter is the Directive on Infrastructure of Spatial Information - INSPIRE [Directive 2007], and its transposition into Polish conditions is contained in the Act on spatial information infrastructure [Act 2010].

E-services for the residents of Częstochowa were developed in a project co-financed by the European Union from the European Regional Development Fund under the Regional Operational Program of the Silesia Region for the years 2007-2013. The project is implemented as part of the North Sub-region Development Program [Fundusze Europejskie, portal in Częstochowa (10.01.2019)]. The total cost of the project was PLN 7,437,453.73. The subsidy from European Union funds amounted to PLN 6,318,211.04. As part of the project of "E-services for the residents of Częstochowa", four systems were created:

- Integrated Spatial Information System (ZSIP) - an IT tool that will enable the gathering, processing and sharing of databases and collections containing information on the geographical space of the city and the state of land development.

- City Safety Support System (SWB) - a tool dedicated to the employees of the City Council dealing with crisis management and providing adequate spatial data to the relevant ZSIP services. Some of the information will be made available to the residents.

- Investor and Real Estate Geoportal System (GRN) - a tool that includes spatial and descriptive information about investment processes and the economic structure of the city area. This tool is dedicated to investors who will have access to: local spatial development plan, utility networks, real estate maps, and other information.

- System of Contracting Visits at the Office (SUW) - a platform aimed at shortening the time of servicing the clients by providing electronic services.

The E-services portal for the residents of Częstochowa is a modern IT system, supporting the communication between administration officials and the Office's clients. The main purpose of implementing the said system has been to increase the availability and scope of public services carried out electronically, to simplify and speed 
up administrative procedures as well as to increase the efficiency and transparency of the Częstochowa City Council [e-usługi (e-services) web portal for the residents of Częstochowa - a municipal service (10/01/2019)].

The e-usługi (e-services) portal for the residents of Częstochowa consists of the following elements, marked with letters A through $\mathrm{H}$ in Figure 1:

- A - city service tab containing information about the city of Częstochowa,

- B - resident's geoportal service aimed at providing access to spatial data, and services related to these data. Data are presented in the form of raster and vector maps. The portal makes it possible to create your own mapping compositions,

- C - online office tab through which it is possible to provide services electronically, in order to shorten the time of handling the client's request,

- D - acoustic map developed on the basis of road, rail, tram and industrial noise measurements,

- E-metadata portal website providing metadata obtained by the City of Częstochowa and made available in the system,

- F - investor's geoportal containing basic information about the city, applicable administrative procedures, spatial and tax policy as well as investment offers in Częstochowa,

- $\mathrm{G}$ - training portal - according to the name, the portal is of a training nature. There is a course explaining the operation of particular functions and geoportal tools,

- $\mathrm{H}$ - tourist's portal providing broad access to information about Częstochowa, especially those related to the tourism aspect of the city.

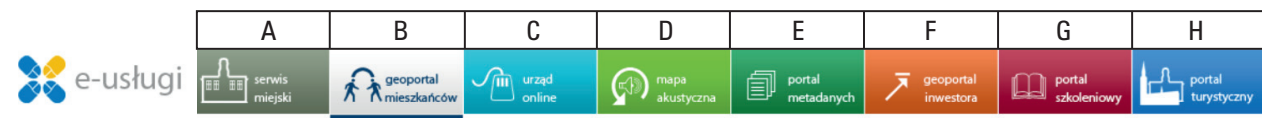

Source: elaborated by the authors based on http://e.czestochowa.pl/geoportaltoolkit/map.php (accessed: 10 January 2019)

Fig. 1. Contents of e-usługi (e-services) web portal for Częstochowa city

\section{Analysis of the content of the web portal's databases}

The layout of the home page of the residents' geoportal is divided into 5 main elements: heading - containing links to individual services, portals and geoportals; function bar with tools, map window with basic panel, and footer.

Each of the thematic profiles in the basic panel is intended for a different type of recipient. The following profiles are distinguished:

- The resident's geoportal was created to improve the quality of life of the inhabitants. The basic function of the portal is to present data on the orthophotomap back- 
ground. The map contains information about the location of public utilities as well as other important places from the point of view of the city's residents.

- The investor's geoportal was created for potential investors and entities conducting business activity.

- Civic Budget is a public consultation portal concerning the spending of a portion of the money in the budget of the City of Częstochowa.

- Revitalization of the city areas is a profile containing information about the areas covered by the revitalization project, that is, actions aimed at restoring the areas currently in the state of crisis resulting from economic and social factors.

- Preservation of heritage is intended as a portal showing the areas and buildings listed in the register of monuments. However, all layers available within it are duplicated with the layers available on other thematic profiles, and none of the available layers contains information about monuments located throughout the city.

- Acoustic map was created in accordance with the Act Environmental Protection Law [Act 2001] and Directives of the European Parliament and Council [Directive 2002], relating to the assessment and management of noise in the environment.

\section{Material and methods}

The data made available in the spatial information system can significantly accelerate and facilitate the real estate valuation process. In order to assess the suitability of the local spatial information system in Częstochowa for the stated purpose, 3 real estate properties located within the city were selected. Then, the information provided by the e-services portal was analysed in order to obtain data for the needs of property valuation. The selected properties are the monastery complex at Jasna Góra (1), the Arena Częstochowa Municipal Stadium (2), and the building of the Jarosław Dąbrowski High School No. 6 in Częstochowa (3). The location of selected properties is presented below (Fig. 2). The present research is an element of scientific and research work conducted at the Department of Geodesy of the University of Agriculture in Kraków. The analysed objects are described in detail in the work by Zborowska [2017].

The most important stage in the analysis for the purposes of this publication was the comparison between spatial information systems in Częstochowa, Kraków, Wrocław and Warsaw. Selected geoportals were analysed according to arbitrarily accepted comparative features, which at the same time constitute information that is significant from the point of view of real estate property valuation. This data derives from the range of land and building records, geodetic records of utilities networks, administrative division, ownership and possession structure, spatial planning, land and soil quality classes, restrictions and threats, vegetation, price and value record, information about heritage monuments, demographics, as well as location of public facilities (Table 1). The presence of a given feature is marked with the "+" sign, and its absence is marked with the "_" sign. 


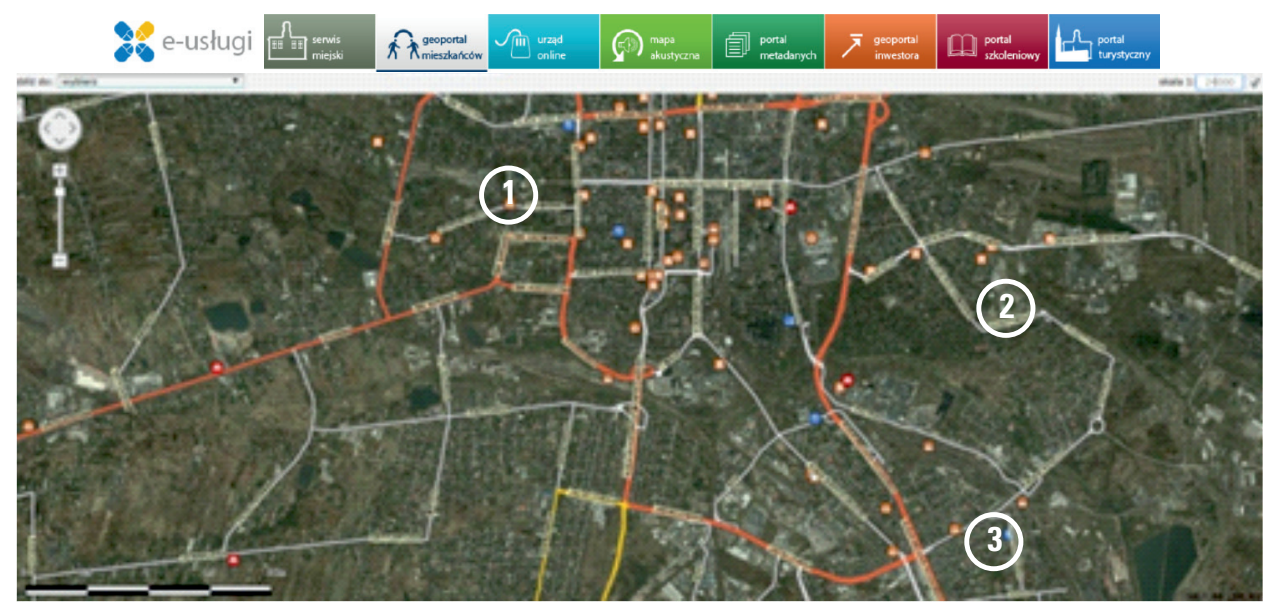

Source: elaborated by the authors based on http://e.czestochowa.pl/geoportaltoolkit/map.php (accessed: 10 January 2019)

Fig. 2. Placement of real estate properties selected for analysis within the Częstochowa area

\section{Results}

The results of the analysis of four geoportals in the scope of the selected information are presented in the table 1 .

The Summary of information in the table above shows that the most useful spatial information system, in terms of detail and availability of information for the needs of the valuation, is the City Information System of the City of Kraków. The said portal contains full data in 8 out of 12 highlighted categories of information. Data in other categories are incomplete. However, the Kraków system lacks information about the location of public facilities, which constitutes a factor in the analysis for the needs of real estate property valuation.

The portal of the Spatial Information System for the city of Częstochowa oscillates at a similar level to the Municipal Spatial Information System in Wrockaw and the Spatial Information System of the capital city of Warsaw. The biggest deficiency of the spatial information system is the lack of data on geodetic record of utilities, the register of prices and property values, and information on heritage monuments. 


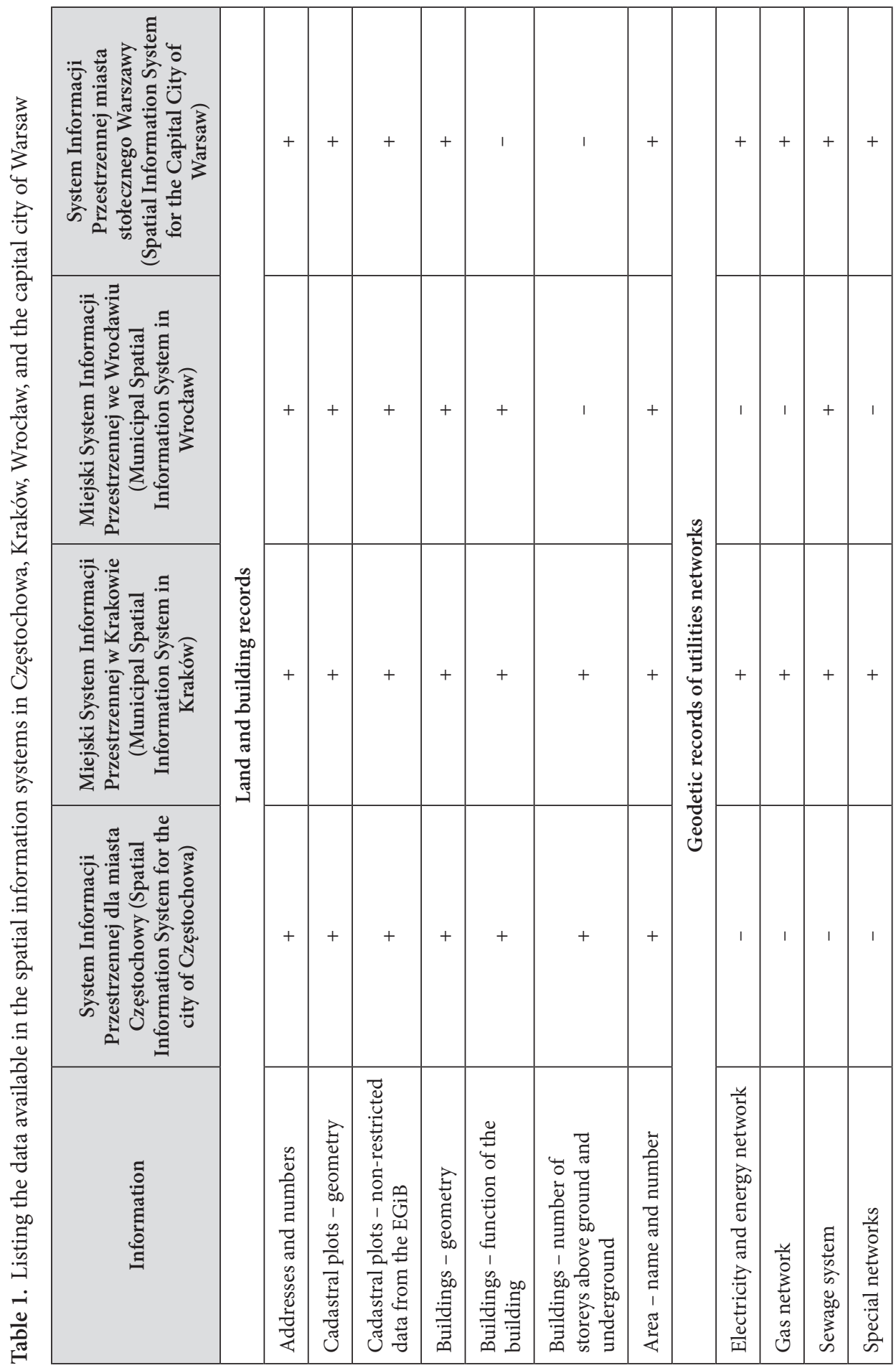




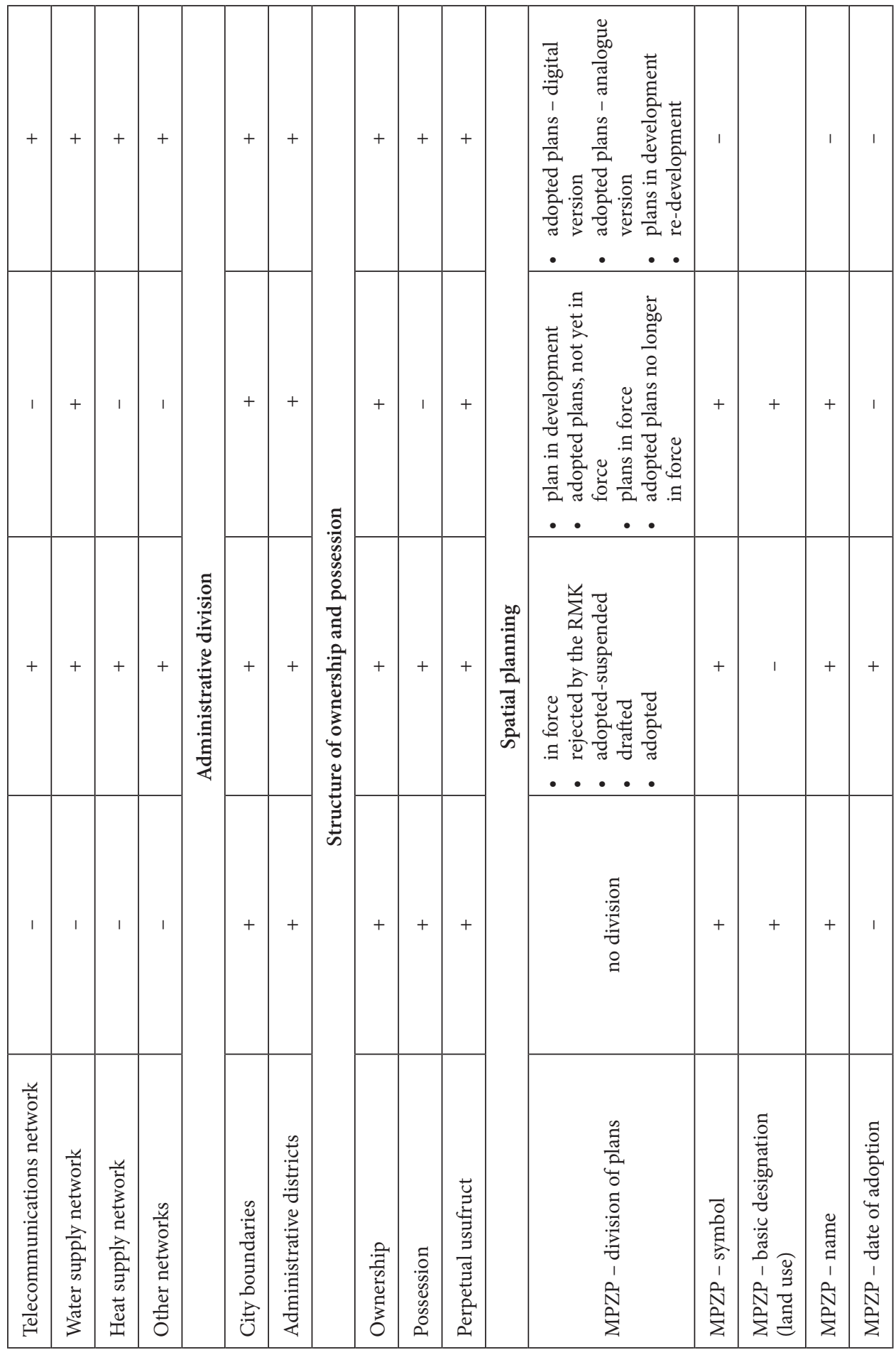




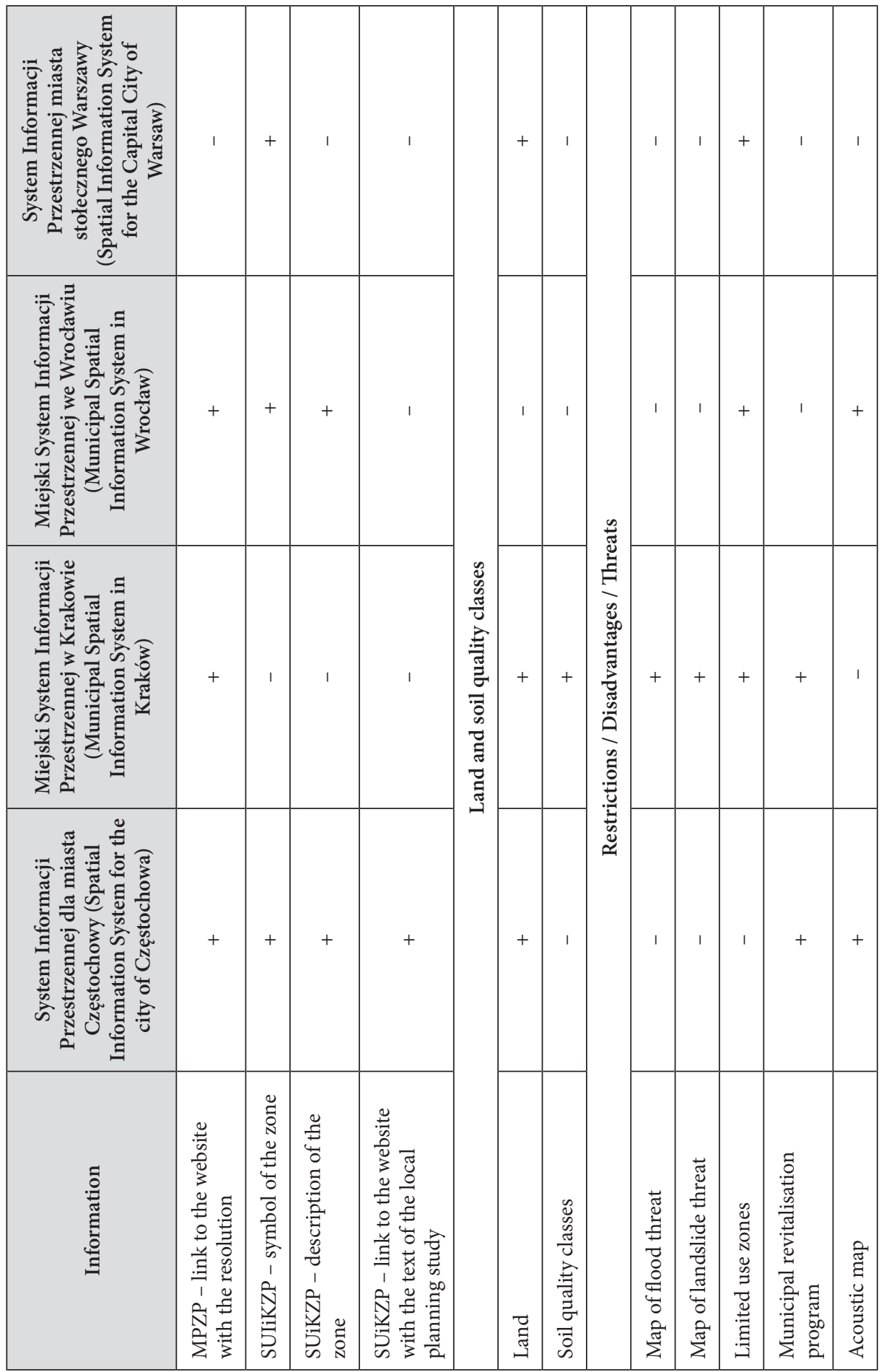




\begin{tabular}{|c|c|c|c|c|c|c|c|c|c|}
\hline & 1 & 1 & \multirow{5}{*}{ 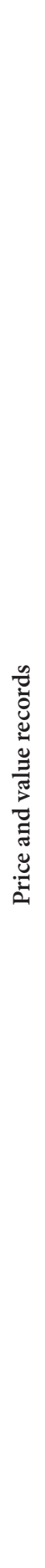 } & 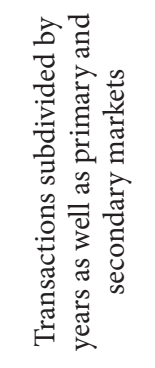 & 1 & 1 & \multirow{5}{*}{ 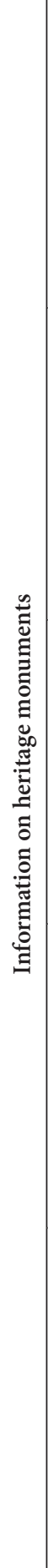 } & + & 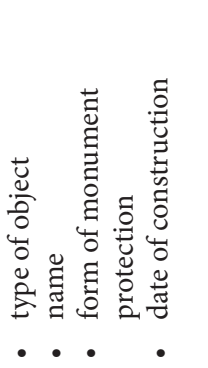 \\
\hline & 1 & 1 & & 1 & 1 & 1 & & + & 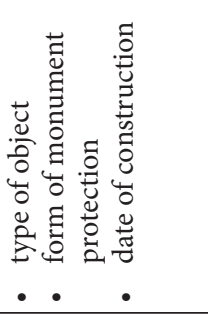 \\
\hline 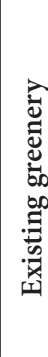 & 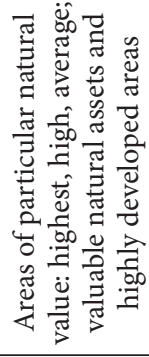 & 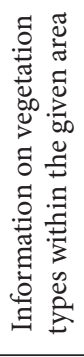 & & 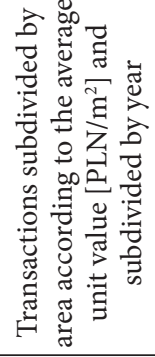 & 1 & 1 & & + & 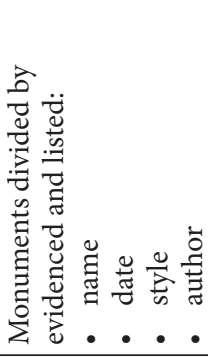 \\
\hline & 1 & 1 & & 1 & 1 & 1 & & 1 & 1 \\
\hline & 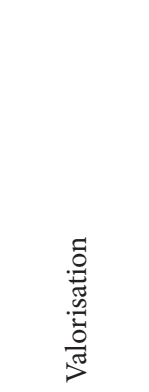 & 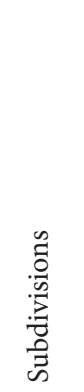 & & 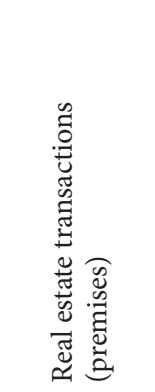 & 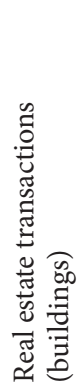 & 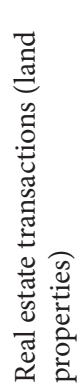 & & 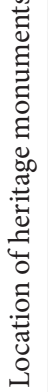 & 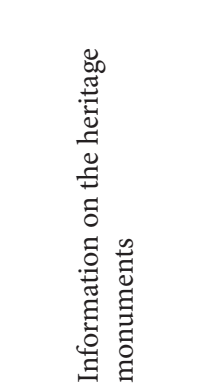 \\
\hline
\end{tabular}




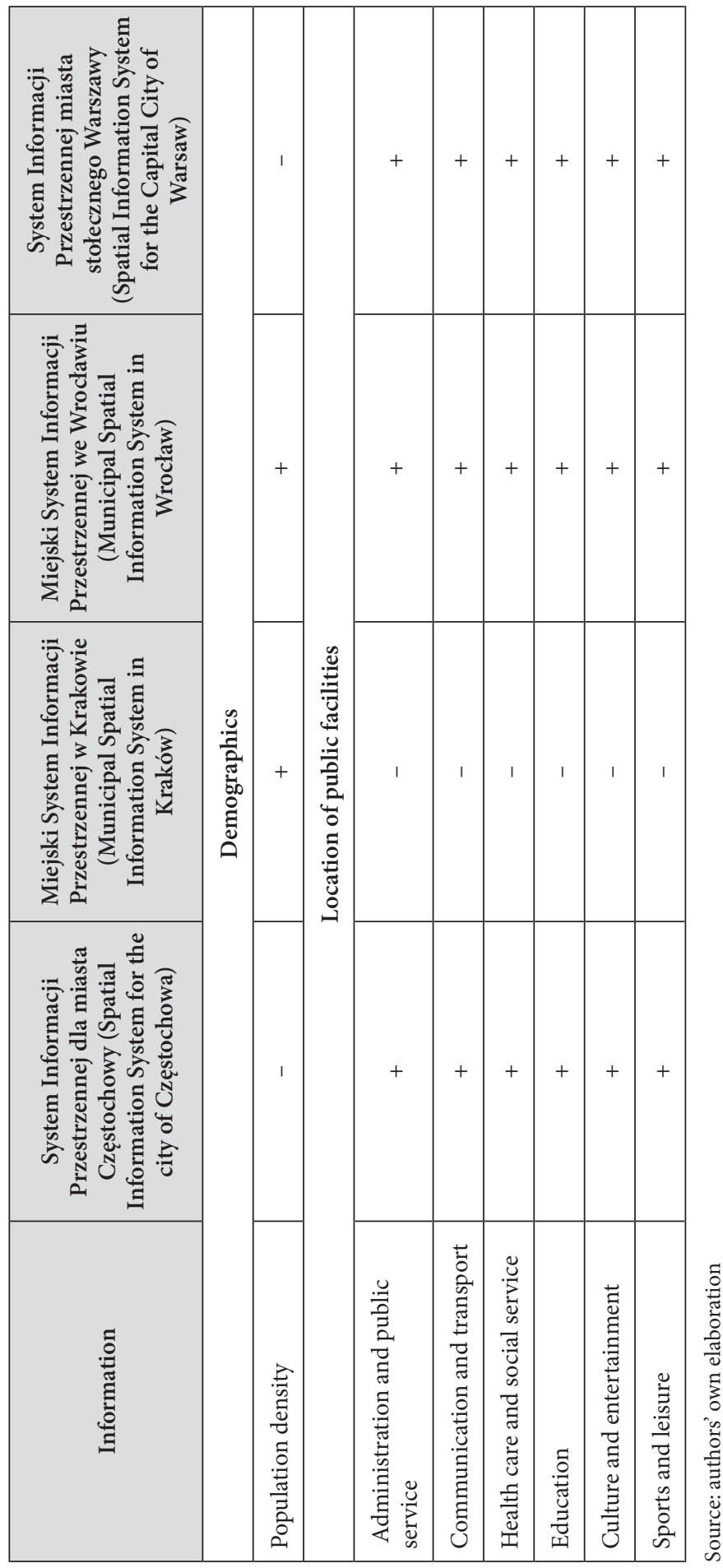




\section{Conclusions}

Based on the analysis of the local spatial information system in Częstochowa, we can conclude that the scope of data available in it for users is not sufficient. The comparison of the Częstochowa system with other systems such as MSIP Kraków, MSIP Wrocław and SIP of the capital city of Warsaw made it possible to state that the analysed system deviates from them both in terms of the scope of information and the quality of the cartographic representation of the data. Information useful for real estate appraisal, available in the Częstochowa spatial information system, is limited to data from land and building records, information on the spatial location of the property, information about the property's neighbourhood, information about the ownership structure and usufruct of land, and information on land allocation in the Local Development Plan (MPZP) or local land use study (SUiKZP). Based on the analyses and research carried out, it can be concluded that the system can be improved by creating base maps. A good benchmark solution in this area is provided by the MSIP for the city of Krakow. Following that example would have a positive impact on the legibility of the cartographic elaboration contained in Częstochowa's system. Furthermore, the processes for authorising all operations on layer should be improved, and that authorisation should be done automatically. This change would significantly speed up work in the system, and would have a positive impact on the user's work comfort. The thematic profiles of the Częstochowa portal should be enriched with specific information useful from the point of view of potential users. From the point of view of real estate property appraisal, the system's database should be extended - primarily with information on the utilities network, land valuation classes, location of heritage monuments, location of hazard zones, and in further stages also with information from the price and value register. The system also requires changes to the scope of data updating, especially as regards legal data about real estate. The introduction of the suggested changes could increase the system's functionality not only for the needs of the appraisers, but also for other entities in the real estate market. The MSIP of the city of Kraków or the SIP of the capital city of Warsaw could serve as benchmark models.

\section{References}

Aranas Romer K., Gonzalez R., Balicanta L. 2014. Linking the Land Information Systems in the Philippines Using the LADM as a Global Schema. 25th FIG Congress, June 2014, Kuala Lumpur.

Dawidowicz A., Klimach A. 2017. The development of Local Land Information Systems in the Rural Municipalities. Geomatics and Environmental Engineering, 11(1), 33-46.

Dukaczewski D. 2007. Wojewódzkie portale informacji przestrzennej. Roczniki Geomatyki, T.V. 3, 37-55.

Directive 2002. Dyrektywa 2002/49/WE Parlamentu Europejskiego i Rady z dnia 25 czerwca 2002 r. odnosząca się do oceny i zarządzania poziomem hałasu w środowisku.

Directive 2007. Dyrektywa 2007/2/WE Parlamentu Europejskiego i Rady z dnia 14 marca 2007 r. ustanawiająca infrastrukturę informacji przestrzennej we Wspólnocie Europejskiej (INSPIRE). 
Elia E., Zevenbergen J., Lemmen C., Van Oosterom P. 2013. The land administration domain model (LADM) as the reference model for the Cyprus land information system (CLIS). Survey Reviev, 45, 100-110.

e-usługi dla mieszkańców Częstochowy - geoportal mieszkańców, http://e.czestochowa.pl/geoportaltoolkit/map.php (accessed: 10.01.2019).

e-usługi dla mieszkańców Częstochowy - serwis miejski, http://e.czestochowa.pl/serwis-glowny /?IdKat=1400001005\&IdStr=1400001033 (accessed: 10.01.2019).

Fourie C. 1998. An integrated geo-information system with emphasis on cadastre and land information systems for decision makers in Africa. Working Document for the Expert Group Meeting held at United Nations Economic Commission for Africa, Addis Abeba, Ethiopia, 23-26 November.

Fourie C., Nino-Fluck O. 2000. Cadastre and land information systems for decision makers in the developing world. Paper presented at the UN-FIG Conference on Land Tenure and Cadastral Infrastructures for Sustainable Development, Melbourne, Australia.

Fundusze Europejskie w Częstochowie, http://www.fe.czestochowa.pl/page/2986,e-uslugi-dla-mieszkancow-czestochowy.html (accessed: 10.01.2019).

Gaździcki J. 1990. Systemy informacji przestrzennej. PPWK, Warszawa-Wrocław.

Jurkiewicz M. 2015. Ocena danych katastralnych w geoportalach poziomu lokalnego tworzonych w różnych środowiskach programowych. Episteme. Czasopismo Naukowo-Kulturalne, 26, II, 67-73.

Kozubek E., Werner P. 2009. Ocena portali internetowych gmin i powiatów. Roczniki Geomatyki, 36, 81-87.

Kwartnik-Pruc A. (red.), Bacior S., Bieda A., Mika M., Pęska A., Siejka M., Trembecka A., Wróbel A. 2015. Rola danych geodezyjnych w wybranych procesach gospodarki nieruchomościami. Wyższa Szkoła Inżynieryjno-Ekonomiczna, Rzeszów.

Leń P., Tempiński B. 2015. Ocena stanu uzbrojenia terenu w sieć wodno-kanalizacyjną z wykorzystaniem narzędzi GIS. Motrol. Motoryzacja i Energetyka Rolnictwa, 17, 1, 67-72.

Miejski System Informacji Przestrzennej w Krakowie, http://obserwatorium.um.krakow.pl/obserwatorium/kompozycje/?lang=pl (accessed: 10.01.2019)

Mika M. 2017. Proposed model for data security protection of cadastral information in Poland. Geomatics, Landmanagement and Landscape, 1, 81-91.

Nkambwe M. 2001. Land information systems development and the national spatial data infrastructure in Botswana. The International Archives of the Photogrammetry, Remote Sensing and Spatial Information Sciences, XXXIV, 6/W6.

Redman T. 2001. Data quality. The Field Guide, Digital Press, Boston, 233.

Siejka M. 2011. Aspekty wykorzystania aktywnych baz danych w wycenie nieruchomości. Infrastruktura i Ekologia Terenów Wiejskich, 3, 235-250.

Siejka M., Ślusarski M. 2012. Próba oceny jakości informacji o środowisku dostępnych w geoportalach na przykładzie wybranych miast powiatowych. Czasopismo Techniczne, 2-Ś/2012 (23), 227-236.

Siejka M., Ślusarski M. 2013. Analiza jakościowa danych geodezyjnej ewidencji sieci uzbrojenia terenu. Infrastruktura i Ekologia Terenów Wiejskich, 2/III, 119-126.

Siejka M., Ślusarski M. 2014. Ocena geoportali internetowych powiatów, na wybranych przykładach oraz według ustalonych kryteriów. Infrastruktura i Ekologia Terenów Wiejskich, II/2, 545-555.

System Informacji Przestrzennej Wrocławia, http://www.geoportal.wroclaw.pl (accessed: 10.01.2019). 
System Informacji Przestrzennej miasta stołecznego Warszawy, http://www.mapa.um.warszawa. $\mathrm{pl} / \mathrm{mapaApp} 1 / \mathrm{mapa}$ ? service $=\mathrm{rciwn} \& \mathrm{~L}=\mathrm{pl} \& \mathrm{X}=7502805.127594725 \& \mathrm{Y}=5788955.369500488$ $\& \mathrm{~S}=2 \& \mathrm{O}=0 \& \mathrm{~T}=0$ \&komunikat $=$ off (accessed: 10.01.2019).

Ślusarski M. 2006. Ocena porównawcza jakości danych lokalnych systemów geoinformacyjnych. Zesz. Nauk. AR w Krakowie, 431, ser. Geodezja, 22, 211-216.

Ślusarski M. 2012a. Doskonalenie jakości informacji w powiatowych systemach geoinformacyjnych. Infrastruktura i Ekologia Terenów Wiejskich, 1/III, 41-47.

Ślusarski M. 2012b. Propozycja oceny geoportali internetowych poziomu lokalnego. Infrastruktura i Ekologia Terenów Wiejskich, 1/III, 109-115.

Act 2001. Ustawa z dnia 27 kwietnia 2001 r. Prawo ochrony środowiska (Dz. U. z 2001 r. Nr 62, poz. 627).

Act 2010. Ustawa $\mathrm{z}$ dnia 4 marca 2010 r. o infrastrukturze informacji przestrzennej (Dz. U. z 2010 r. Nr 76, poz. 489).

Williamson I.P. 1985. Cadastres and land information systems in common law jurisdictions. Survey Review, 28, 217, 114-119.

Zborowska A. 2017. Analiza Lokalnego Systemu Informacji Przestrzennej w Częstochowie pod kątem szczegółowości informacji na potrzeby wyceny nieruchomości, praca magisterska wykonana w ramach badań prowadzonych w Katedrze Geodezji, Uniwersytetu Rolniczego w Krakowie (tekst niepublikowany).

Zhao J., Zhou Y. 1999. The methods of topology building and parcel updating in land information system. Towards Digital Earth, Proceedings of the International Symposium on Digital Earth Science Press, 807-811.

Mgr inż. Magdalena Jurkiewicz Uniwersytet Rolniczy w Krakowie

Katedra Geodezji

31-198 Kraków, ul. Balicka 253a

e-mail: jurkiewicz.m@o2.pl

ORCID: https://orcid.org/0000-0002-5380-5158 